\title{
Personal Security Measures. An Analyze of the Albanian Legislation
}

\author{
Nikolin Hasani, PhD \\ University “Ismail Qemali” Vlore \\ Faculty of Human Sciences, Department of Law \\ nikolin.hasani@univlora.edu.al
}

\begin{abstract}
The personal security measures are directed against the suspected person of the committing a criminal offense depriving of some rights charging him with specific obligations. Referred to Criminal Procedure Code of Republic of Albania personal security measures are divided into coercive measures and prohibitive measures. The Supreme Court by an unifying decision is expressed that ${ }^{1}$ "The distinction between coercive measures and prohibitive measures consists on the fact that in different from coercive measures, they prohibitive can be implemented not for all criminal offenses, but only when is proceeding for criminal offenses for which the law sets a punishment of imprisonment higher in maximum than a year, and the fact that the only purpose of taking these measures is preventive". The aim of this paper is to make an analyze of the Albanian legislation about the personal security measures.
\end{abstract}

Keywords: security measures, personal security measures, legislation.

\section{Introduction}

One of the reasons of assignment and implementation of personal security measures is the need to guarantee in continuity the presence of the defendant in penal proceeding in his charge, as to ensure the normality of the investigation and the trial in the case against him, the need to avoid the risk of committing further offenses by him, as well as to ensure that he does not leave, hide but to undergo to execution so to suffer the sentence when the decision has become final. The security measure set in every stage of proceeding has no connection with the defendant's right to not be present personally at the hearing, or to leave it on his own free. The needs of security are set for the other purposes, they have not any connection or influence on allowing or limiting of the right of defendant to participate in the trial that is held against him. To the defendants with or without security measure is guaranteed the right to participate in the judgment of accusation against him.

\section{Types of coercive measures according to Albanian legislation}

In article 232 of Criminal procedure Code are determined the types of coercive measures. They are:

- Prohibition to leave the country;

- The obligation to appear before the Judicial Police;

- The prohibition and the obligation to stay in a certain location;

- Property guarantee;

- House arrest;

- Arrest in prison;

- Temporary hospitalization in a psychiatric hospital

Some of the personal security measures intended to restrict the right of free movement within and abroad. Such are: the prohibition to leave the country, the obligation to appear before the Judicial Police and the prohibition and obligation to stay

\footnotetext{
${ }^{1}$ Look the decision no.3 date 27 September 2009 of Supreme Court
} 
in a certain location. How can we interpret this ranking of coercive measures, a chronological order or simply as a random order?

\section{Criteria for setting of personal security measures according to the Albanian Legislation}

The security measures are setting when:

- There exist important reasons that put in danger the obtaining or the truthfulness of evidence.

- The defendant has leave or exist the risk that he may leave.

- For the reason of circumstances of fact and of personality of defendant exist the risk that he may commit serious crimes or of the same type with which it proceeded.

Exist important reasons that put in danger the obtaining or the truthfulness of evidence - The evaluation of circumstances on existence or not of the risk for "poisoning" of evidences, is made step by step. Among the other things, can be evidenced the verification that makes the court to the circumstance on the time that has passed from the moment of notifying of the defendant for criminal proceedings against him, in connection with the circumstance if he has committed or may commit any action or behavior that "risks" the process of obtaining and truthfulness of evidence.

In this context, in principle, the right of silence of the defendant as a strategy of his defense does not constitute "risk" that can serve as motivation to request appointment of a security measure against him. However, this circumstance can be evaluated in harmony and in connection with other his behaviors on offense that he has committed and the started criminal proceeding, which could lead the court in the conviction that exists a doubt based on the evidences that the defendant if will be left free he will poison the evidence and the process of verification, such as search, obtaining, authenticity and preservation of evidence and sources of evidence by the defendant.

When the defendant has left or exist the risk that may leave - Relating to this condition for the assignment of security measure, while "escape" "leaving" of defendant is a matter of fact, is the to highlight that the acceptance by the court of the existence of the possibility, so "the risk of leaving", must be motivated, based on concrete elements, on facts and objective circumstances. For the effect of motivation of assignment of security measure, one of cases that constitutes objective element to lead the court in conclusions on leaving or risk of leaving, is the case of leaving without trace of the defendant.

This situation, in itself, embodies logically and legally the defendant's tendency to infringe and not implement security measures, his being permanently in the position of illegal disobedience before the law, the tendency to avoid investigation and trial, and the suffering of punishment. This risk situation normally remain the same even if the defendant declared gone, after shows his availability to be present or when he is presented voluntarily before the authorities of proceeding. If it deems not to participate in the hearing, he is free to not appear or to leave the room, but if he is under the security measure of home arrest or arrest in prison, the defendant necessarily stays or returns to its isolation.

When for the reason of circumstances of fact and of personality of defendant exist the risk that he may commit serious crimes or of the same type with which it proceeded - The content of this disposition relates to the need for the appointment of a security measure to fulfill the special preventive function of state for guarantee of public order and public security, the inviolability of life, health, property and interests and other legal rights from committing of other criminal acts by the defendants. In this regard, to legitimize the restriction of the freedom of the defendant the appointment of security measure, among others, the object of the judgment is the verification of the specific circumstances of fact which serve to the court to assess and to conclude on the risk of author and on the other hand to determine the criminal offenses that can be committed by him.

In this sense, to accept the existence of appropriate security of the concrete risk to the community, the violation of public order and public security, which justify the appointment of security measure under this disposition, subject to judicial investigation should be concrete evaluation of the circumstances of the fact, drawing by the whole behavior of defendant valid concrete elements on which to base the decision giving. 
Based on the evaluation of evidences on existence of concrete elements of circumstances of fact and of the personality of the defendant, not necessarily cumulative, the court concludes that if exist the reasonable suspect about his the dangerousness of and the need to guarantee the inviolability of community, if exist the real possibility that the defendant in the future, being free can commit serious criminal offenses or of the same type as that for which it is proceeded.

"Serious crimes" in the meaning of the letter "c" of paragraph 3 of Article 228 of the Criminal Procedure Code include not only those for which there is competence of Court for Serious Crimes, as well as other serious criminal offenses, which, for their self-danger and consequences, are recognized as such in our judicial practice even before the creation of these court

Article 229 "The criteria for the assignment of security measures" of Criminal Procedure Code:

In the assignment of security measure the court takes in consideration the suitability of each of them to the degree of security needs that must be taken in concrete case.

- Every measure must be in proportion to the importance of the fact and to the punishment provided for the offense in question. Are taken into account the continuity, repetition, and the mitigating and aggravating circumstances provided by the Criminal Code.

- When the defendant is a minor, the court shall consider the request to not interrupting the concrete educational processes.

Article 230 "Special criteria for assignment of measure of arrest in prison" of Criminal Procedure Code:

- Arrest in prison can be set when any other measure is inappropriate for the reason of special the dangerousness of the offense and of defendant. Of course, in evaluating of this criterion may have shown of the subjectivity due to overestimation or not understanding of certain aspects of the case therefore the caution should be special, especially by courts that examine the appeals against measures.

- Cannot be set arrest in prison against an woman who is pregnant or breastfeeding, against a person who is in a especially heavy health or has passed the age of seventy years or to a drug addict or alcoholic, for which is applied a therapeutic program in a special institution. In this disposition come out the human character that characterized the penal law in some cases. It is understood that the definition of pregnancy, serious illness or age must be proven with documents and expertise and justified in given decision. Likewise, when these factors are not taken into account, should be explaining the reasons that make necessary the arrest and the sanction of disposition that provides the criminal offense attributed to the defendant.

- In the cases provided in point 2, the arrest in prison can be set only when there are reasons of a special importance for crimes punishable in maximum not less than ten years imprisonment.

Article 231 "Replacement or merger of personal security measures" of Criminal Procedure Code:

- In case of violation of obligations related to a security measure, the court may decide replacing or merging with another measure heavier, taking into account the importance, motives and circumstances of the offense. For the violation of the obligations related to a prohibitive measure, the court may decide the replacement or merger with a coercive measure.

\section{Conclusions}

Referred to article 228 "the conditions and criteria for assignment of security measures" of Criminal Procedure Code: No one shall be subjected to personal security measures if in his charge does not exist a reasonable suspicion, based on evidences. Through the right analysis and interpretation of this disposition, in particular of the expression "reasonable suspicion, based on evidences", in harmony with the other procedural institutes, can be distinguished and reached to the right conclusions, not only regarding to the prerequisites conditions for setting a security measure but also why this measure can be set in trial phase of the criminal case. Consequently it can be understood and be distinguished the trial on a reasonable suspicion based on evidence for setting of security measure by the judgment of evidence for the purpose to 
form the conviction of the truth, beyond any reasonable doubt in the decision of dismissal, the innocence or conviction of the defendant.

Reasonable suspicion based on evidence according to this paragraph means that it comes to the existence of reasonable suspicion based on evidence, so for the existence of those sufficient legal elements and factual circumstances that create obedience to judges in terms of the possibility that the person under investigation and the defendant has committed the criminal offense.

Consequently, for setting of the security measure is necessary that direct or indirect evidences, be such as to make it seem possible the responsibility of the investigated or the judged about the charges brought against him. So not to find ourselves before a priori procedure.

Suspicion based on evidence does not request to be exhaustive, necessarily one direction, thus in terms of culpability. Despite this reasonable suspicion based on evidence that the judged has committed the offense, at the end of the trial can be certified as a result of defendants guilty, as well as the defendant's innocence.

Therefore, the Joint Colleges come to the unifying conclusion that "reasonable doubt, the evidence where it is based to justify the setting and the continuation of implementation of the security measures, there is no need to have the same degree of security and probative value to conclude as evidence that are necessary for the giving or not of the sentence against the defendant. It is sufficient that they be such that, in the situation where are the acts of the proceedings, from which can take conclusions that against to the investigated or judged exists a reasonable possibility degree of culpability for committing the criminal offense in his charge.

The criteria provided by article 229 of Criminal Procedure Code, even they give to the court a wide discretion to decide clearly, intended the proportionality, specific suitability of type of security measure with self-security needs for that specific case. If there are no reasons to exclude the author from criminal responsibility, these criteria impose the obligation of the court to base the decision on the one hand, on reasonable suspicion based on evidences on the commission of the criminal offense by him and, on the other hand, on the evidences that contains the sufficient objective and subjective elements, the circumstances of the case, which shows that exist the situation of dangerousness, and the level of risk, at least according one of the cases under Article 228.

As in the case when the security measure is set for the first time, also when is considering the replacement of the existing measure, the court has no obligation to analyze why the other types of security measures are not adequate, is sufficient to argue that the measure ordered by it in specific case against the defendant is the appropriate measure. In any case remain the obligation of the court that, initially, to argue that exists a reasonable suspicion based on evidences in charge of the defendant for commission of the criminal offense by him.

Therefore, even when set security measure of arrest in prison, the court is not obliged to analyze in detail why other kinds of measures are not appropriate in the case in trial. Based on objective elements on the nature of the offense, the means and the manner of its commission, the caused consequences, as well as subjective elements related to the personality of the defendant and the state of dangerousness, the court argues that the only appropriate measure against the defendant in proportion to type and level of dangerousness is that of arrest in prison.

Point 3 of this article presents a special importance because it has to do with the minors to which the law recognizes the right to be treated differently from adults and that as a result of their need for a differentiated treatment. At the moment that the court argues that the only appropriate measure to a minor is the arrest in prison, should set him associated with the continuity of the educational process of minor. Only in this way the measure will realize the goal of its setting.

I assess that in paragraph 3 we have to do with a legal deficiency because this article should include the minors and the students. The interruption of the educational process will not bring any good to the student's rehabilitation after committing of a specific criminal offense, except that it will have an adverse impact on his psyche.

Penal Chamber of the Supreme Court, said: "Penal Chamber assesses that in setting as the security measure "arrest in prison" are not taken into account the general criteria for setting of security measures and specific circumstances of the case. The courts have not done an analysis of specific dangerousness of author, but they are satisfied with citation of dangerousness of the criminal offenses committed in collaboration and its spread. In view of the evidence gathered by the prosecution, this college without wanting to enter in their analysis at this stage of the preliminary investigation, in this case 
has taken into account several criteria for changing of the measure of personal security given to the person under investigation, such as: The fact that leaving free the person under investigation does not risk the obtaining of new evidences related to probationary of the elements of the criminal offense for which the prosecution is investigating The fact that has two children one of them is minor, the fact the husband is invalid and is treated with work disability payment; the fact that the suspected person in the detention facilities has shown health problems and is recommended to be hospitalized. And in the end it is not certified the existence of circumstances in proportion to the crime and its suspected author"..

\section{References}

Anastasi, A. \& Omari, L. (2010), E drejta Kushtetuese, Ribotim. Tiranë 2010.

Anastasi, A., \& Omari, L. (2010). E drejta kushtetuese, Ribotim. Tiranë 2010, fq. 139-140.

Elezi, I. (1997). Zhvillimi i legjislacionit penal shqiptar.

Elezi, I. (2001). Komentar i shtesave dhe ndryshimeve në Kodin Penal. Albin, Tiranë 2001.

Elezi, I. (2002). E drejta penale e Republikes se Shqiperise. Tirane, 2002.

Elezi, I. (2004). Komentari i shtesave dhe ndryshimeve të reja në Kodin Penal 2003- 2004. Albin, Tiranë, 2004.

Elezi, I. (2005). E drejta Penale Pjesa e Posaçme. Tiranë 2005.

Elezi, I. (2007). E Drejta Penale, Pjesa Posaçme. Botime Erik, 2007

Elezi, I. (2008). E drejta penale - Pjesa e përgjithshme. 2008.

Ligji nr. 7574, datë 24.06.1992 "Për organizimin e drejtësisë dhe disa ndryshime në kodet e procedurave penale e civile".

Neni 13 "Gjykatat penale të shkallës së parë dhe përbërja e tyre", Kodi i Procedures Penale të Republikës së Shqipërisë.

Neni 145/2 i Kushtetutës së Republikës së Shqipërisë.

Neni 228 "Kushtet për caktimin e masave të sigurimit personal", Kodi i Procedures Penale të Republikës së Shqipërisë.

Neni 229 "Kriteret për caktimin e masave të sigurimit personal" Kodi i Procedures Penale të Republikës së Shqipërisë.

Neni 230 "Kriteret e veçanta për caktimin e masës së arrestit në burg", Kodi i Procedures Penale të Republikës së Shqipërisë.

Neni 231 "Zëvendësimi ose bashkimi i masave të sigurimit personal", Kodi i Procedures Penale të Republikës së Shqipërisë.

Neni 244 "Kërkesa për caktimin e masave të sigurimit", Kodi i Procedures Penale të Republikës së Shqipërisë.

Neni 244 "Kërkesa për caktimin e masave të sigurimit", paragrafi 3, Kodi i Procedures Penale të Republikës së Shqipërisë.

Neni 244/3 Kodi i Procedures Penale të Republikës së Shqipërisë.

Neni 246 "Zbatimi i masave të sigurimit", Kodi i Procedures Penale të Republikës së Shqipërisë.

Neni 248 "Marrja në pyetje e personit të arrestuar", Kodi i Procedures Penale të Republikës së Shqipërisë.

Neni 248 "Marrja në pyetje e personit të arrestuar", Kodi i Procedures Penale të Republikës së Shqipërisë.

Neni 249 "Ankimi kundër masave të sigurimit", Kodi i Procedures Penale të Republikës së Shqipërisë.

Neni 253 "Ndalimi i të dyshuarit për një krim", Kodi i Procedures Penale të Republikës së Shqipërisë.

Neni 260 "Revokimi dhe zëvendësimi i masave të sigurimit", Kodi i Procedures Penale të Republikës së Shqipërisë. 
Neni 260 "Revokimi dhe zëvendësimi i masave të sigurimit", paragrafi 3, Kodi i Procedures Penale të Republikës së Shqipërisë.

Neni 263 "Afatet e kohëzgjatjes së paraburgimit", Kodi i Procedures Penale të Republikës së Shqipërisë.

Neni 263 "Afatet e kohëzgjatjes së paraburgimit", Kodi i Procedures Penale të Republikës së Shqipërisë.

Neni 263/4 të K.Pr.Penale Kodi i Procedures Penale të Republikës së Shqipërisë.

Neni 265 Kodi i Procedures Penale të Republikës së Shqipërisë.

Neni 266 "Disponimet në rastet e lirimit nga burgu", Kodi i Procedures Penale të Republikës së Shqipërisë.

Neni 28 i Kushtetutës së Republikës së Shqipërisë

Neni 28 i Kushtetutës të Republikës së Shqipërisë

Neni 295 "Identifikimi i personit ndaj të cilit zhvillohen hetimet", Kodi i Procedures Penale të Republikës së Shqipërisë.

Neni 34 "Marrja e cilësisë së të pandehurit", Kodi i Procedures Penale të Republikës së Shqipërisë.

Neni 342 Kodi i Procedures Penale të Republikës së Shqipërisë.

Neni 373 "Akuza për një vepër tjetër", Kodi i Procedures Penale të Republikës së Shqipërisë.

Neni 374 "Akuza për një fakt të ri”, Kodi i Procedures Penale të Republikës së Shqipërisë.

Neni 415 Kodi i Procedures Penale të Republikës së Shqipërisë.

Neni 43 i Kushtetutës së Republikës së Shqipërisë.

Neni 49 "Mbrojtësi i caktuar", Kodi i Procedures Penale të Republikës së Shqipërisë.

Neni 59 "I dëmtuari akuzues”, paragrafi 2, Kodi i Procedures Penale të Republikës së Shqipërisë.

Neni 8 të Deklaratës Universale të të drejtave të njeriut.

Neni 88 "Masat e sigurimit të vendosura nga gjykata jokompetente", Kodi i Procedures Penale të Republikës së Shqipërisë.

Vendimi nr. 01, datë 08.01.2001, të Kolegjit Penal të Gjykatës së Lartë të Republikës së Shqipërisë.

Vendimi nr. 122, datë 06.09.2001, të Kolegjit Penal të Gjykatës së Lartë të Republikës së Shqipërisë.

Vendimi nr. 142, datë 04.02.2001 i Kolegjit Penal të Gjykatës së Lartë te Republikes se Shqiperise

Vendimi nr. 457, datë 20.07.2001, të Kolegjit Penal të Gjykatës së Lartë të Republikës së Shqipërisë.

Vendimi nr. 46, datë 28.01.1999, të Kolegjeve të Bashkuara të Gjykatës së Lartë të Republikës së Shqipërisë.

Vendimi nr. 478, datë 06.09.2001, të Kolegjit Penal të Gjykatës së Lartë të Republikës së Shqipërisë.

Vendimi nr. 489, datë 12.12.2000, të Kolegjit Penal të Gjykatës së Lartë të Republikës së Shqipërisë.

Vendimi nr. 58, datë 05.12.1997, të Gjykatës Kushtetuese të Republikës së Shqipërisë.

Vendimi nr.489, datë 12.12.2000, të Kolegjit Penal të Gjykatës së Lartë të Republikës së Shqipërisë. 